\title{
Methylocapsa aurea sp. nov., a facultative methanotroph possessing a particulate methane monooxygenase, and emended description of the genus Methylocapsa
}

Correspondence

Svetlana N. Dedysh dedysh@mail.ru

\author{
Peter F. Dunfield, ${ }^{1,2}$ Svetlana E. Belova, ${ }^{3}$ Alexey V. Vorob'ev, ${ }^{3}$ \\ Sabrina L. Cornish ${ }^{1}$ and Svetlana N. Dedysh ${ }^{3}$ \\ ${ }^{1}$ Department of Biological Sciences, University of Calgary, Calgary, Alberta T2N 1N4, \\ Canada \\ ${ }^{2}$ Max-Planck-Institute for Terrestrial Microbiology, D-35043 Marburg, Germany \\ ${ }^{3}$ S. N. Winogradsky Institute of Microbiology, Russian Academy of Sciences, Moscow 117312, \\ Russia
}

An aerobic, methanotrophic bacterium, designated $\mathrm{KYG}^{\top}$, was isolated from a forest soil in Germany. Cells of strain $\mathrm{KYG}^{\top}$ were Gram-negative, non-motile, slightly curved rods that multiplied by binary fission and produced yellow colonies. The cells contained intracellular granules of poly- $\beta$-hydroxybutyrate at each cell pole, a particulate methane monooxygenase (pMMO) and stacks of intracytoplasmic membranes (ICMs) packed in parallel along one side of the cell envelope. Strain $\mathrm{KYG}^{\top}$ grew at $\mathrm{pH} 5.2-7.2$ and $2-33^{\circ} \mathrm{C}$ and could fix atmospheric nitrogen under reduced oxygen tension. The major cellular fatty acid was $\mathrm{C}_{18: 1} \omega 7 \mathrm{c}(81.5 \%)$ and the DNA G $+\mathrm{C}$ content was $61.4 \mathrm{~mol} \%$. Strain $\mathrm{KYG}^{\top}$ belonged to the family Beijerinckiaceae of the class Alphaproteobacteria and was most closely related to the obligate methanotroph Methylocapsa acidiphila B2 ${ }^{\top}$ (98.1\% 16S rRNA gene sequence similarity and $84.7 \%$ pmoA sequence similarity). Unlike Methylocapsa acidiphila $\mathrm{B}^{\top}{ }^{\top}$, which grows only on methane and methanol, strain $\mathrm{KYG}^{\top}$ was able to grow facultatively on acetate. Facultative acetate utilization is a characteristic of the methanotrophs of the genus Methylocella, but the genus Methylocella does not produce pMMO or ICMs. Strain $\mathrm{KYG}^{\top}$ differed from Methylocapsa acidiphila $\mathrm{B}^{\top}{ }^{\top}$ on the basis of substrate utilization pattern, pigmentation, $\mathrm{pH}$ range, cell ultrastructure and efficiency of dinitrogen fixation. Therefore, we propose a novel species, Methylocapsa aurea sp. nov., to accommodate this bacterium. The type strain is $\mathrm{KYG}^{\top}$ (=DSM $22158^{\top}=$ VKM B-2544 ${ }^{\top}$.
All known aerobic methanotrophic bacteria belong to the phyla Proteobacteria or Verrucomicrobia (Op den Camp et al., 2009). The proteobacterial methanotrophs are affiliated to two families of the Alphaproteobacteria (Methylocystaceae and Beijerinckiaceae) and one family of the Gammaproteobacteria (Methylococcaceae). The family Beijerinckiaceae is particularly metabolically diverse and contains obligate and facultative methanotrophs and non-methanotrophic chemohetero-

Abbreviations: ICM, intracytoplasmic membrane; pMMO, particulate methane monooxygenase; sMMO, soluble methane monooxygenase.

The GenBank/EMBL/DDBJ accession numbers for the 16S rRNA, pmoA, mxaF and nifH gene sequences of strain $\mathrm{KYG}^{\top}$ are FN433469FN433472, respectively.

A figure showing the effect of $\mathrm{pH}$ on growth of strain $\mathrm{KYG}^{\top}$ is available as supplementary material with the online version of this paper. trophs. The two methanotrophic genera in this family, Methylocella and Methylocapsa, are abundant in acidic soils and peats (Dedysh et al., 2001, 2003) and are physiologically distinct from each other. Methylocapsa acidiphila is an obligate methanotroph capable of growth only on one-carbon substrates. It has a particulate methane monooxygenase (pMMO) and an extensive intracytoplasmic membrane (ICM) system (Dedysh et al., 2002). In contrast, Methylocella species are the only known methanotrophs that lack pMMO and use only a soluble methane monooxygenase (sMMO) for methane oxidation. The genus Methylocella contains the first-described facultative methanotrophs and they are capable of growth on a few multicarbon substrates as well as methane (Dedysh et al., 2005). Here, we describe the isolation of a new methanotroph in the family Beijerinckiaceae. 
Strain $\mathrm{KYG}^{\mathrm{T}}$ was isolated from a soil sample collected in March 2003 from under a small ephemeral brook in a forest near Marburg, Germany. Plates of solid diluted nitrate mineral salts medium at $\mathrm{pH} 5.8$ (DNMS; Dunfield et al., 2003) were inoculated with soil and incubated at $25{ }^{\circ} \mathrm{C}$ in a closed glass desiccator containing a headspace of $20 \%$ methane (v/v) and $5 \% \mathrm{CO}_{2}$ in air for 2 months. During this time, yellowish colonies of irregular shape developed. Strain $\mathrm{KYG}^{\mathrm{T}}$ was obtained from a single colony and purified by successive streaking. Once a pure culture had been obtained, strain $\mathrm{KYG}^{\mathrm{T}}$ was maintained by transfer at 1 -month intervals to $120-\mathrm{ml}$ serum vials containing $20 \mathrm{ml}$ liquid DNMS. Vials were sealed with rubber septa and $20 \%$ methane and $5 \% \mathrm{CO}_{2}$ were added aseptically using syringes equipped with disposable filters $(0.22 \mu \mathrm{m})$. Vials were incubated on a rotary shaker (120 r.p.m.) at $24{ }^{\circ} \mathrm{C}$.

Three strains of Methylocapsa acidiphila were used as reference strains in this study: $\mathrm{B}^{\mathrm{T}}$, V1 and N2. Strains V1 and N2 were newly isolated from an acidic peat soil ( $\mathrm{pH}$ 3.8) sampled at a depth of $10 \mathrm{~cm}$ of the oligomesotrophic fen Torfjanoye, Archangelsk region, European North Russia $\left(65^{\circ} 01^{\prime} \mathrm{N} 35^{\circ} 44^{\prime} \mathrm{E}\right)$ in June 2006. These strains were isolated using liquid mineral medium at pH 5.0 (M2; Dedysh et al., 1998) and were identified as Methylocapsa acidiphila on the basis of 99.9-100\% 16S rRNA gene sequence similarity with Methylocapsa acidiphila $\mathrm{B}^{\mathrm{T}}$.

Morphological observations and cell size measurements were made with an Axioplan 2 microscope and Axiovision 4.2 software (Carl Zeiss). Ultrathin sections were prepared as described previously (Dedysh et al., 2000) and examined on a JEM-100C transmission electron microscope (JEOL). The absence of heterotrophic satellites in strain $\mathrm{KYG}^{\mathrm{T}}$ was checked by phase-contrast and electron microscopy and growth on solid DNMS amended with $0.05 \%$ (w/v) glucose, fructose or yeast extract. Physiological tests were carried out on cultures grown in liquid DNMS with methane as the sole substrate. Growth of strain $\mathrm{KYG}^{\mathrm{T}}$ under a variety of conditions, including $2-37{ }^{\circ} \mathrm{C}, \mathrm{pH} 3.9-$ 8.0 and $0-3.0 \%(\mathrm{w} / \mathrm{v}) \mathrm{NaCl}$, was monitored by nephelometry at $410 \mathrm{~nm}$ using a Specol spectrophotometer (Carl Zeiss) for 3 weeks. Utilization of the following carbon sources $(0.05 \%, \mathrm{w} / \mathrm{v})$ was examined: methanol, ethanol, formate, formaldehyde, glucose, fructose, arabinose, lactose, sucrose, maltose, galactose, acetate, citrate, oxalate, malate, pyruvate and succinate. The capacity to utilize $0.01-5 \%(\mathrm{v} / \mathrm{v})$ methanol was determined in liquid DNMS supplemented with methanol. Nitrogen sources were tested in liquid DNMS by replacing $\mathrm{NaNO}_{3}$ individually with $0.05 \%(\mathrm{w} / \mathrm{v})\left(\mathrm{NH}_{4}\right)_{2} \mathrm{SO}_{4}, \mathrm{NaNO}_{2}$, urea, hydroxylamine, peptone, L-serine, L-proline, L-alanine, L-asparagine and yeast extract. For all substrate utilization tests, growth was examined after 1 month and confirmed by comparison to a negative control. Biomass for cellular fatty acid analysis and DNA extraction was obtained from batch cultures grown at $24{ }^{\circ} \mathrm{C}$ for 10 days. The fatty acid profiles were analysed by the Identification Service of the DSMZ, Braunschweig, Germany, as described by Kämpfer \& Kroppenstedt (1996). The DNA base composition of strains was determined by thermal denaturation using a Unicam SP1800 spectrophotometer with a heating rate of $0.5{ }^{\circ} \mathrm{C} \mathrm{min}^{-1}$. The DNA $\mathrm{G}+\mathrm{C}$ content was calculated according to Owen et al. (1969). The 16S rRNA gene sequence and partial sequences of pmoA and mxaF of strain $\mathrm{KYG}^{\mathrm{T}}$ were determined as described by Heyer et al. (2002). The partial sequence of nifH was determined as described by Dedysh et al. (2004a). Phylogenetic analysis was carried out using the ARB program package (Ludwig et al., 2004).

On solid DNMS, strain $\mathrm{KYG}^{\mathrm{T}}$ formed small, yellow colonies. Colony diameter after 2 weeks was $1-2 \mathrm{~mm}$ and after 6 weeks was $3-5 \mathrm{~mm}$. Colonies were pleomorphic in appearance, ranging from raised, slimy and transparent with a light yellow tint to flat and cream-yellow. Liquid cultures displayed white turbidity. Cells of strain $\mathrm{KYG}^{\mathrm{T}}$ were Gram-negative, non-motile, encapsulated, slightly curved rods, $0.7-1.2 \mu \mathrm{m}$ wide and 1.8-3.1 $\mu \mathrm{m}$ long after incubation for 10 days (Fig. 1a). They reproduced by binary fission and occurred singly or in irregular aggregates. The formation of rosettes was not observed. Cells from older cultures (3-4 weeks) were shorter $(1.1-1.7 \mu \mathrm{m})$ and had a cyst-like shape. Similarly to the genus Methylocella, cells of strain $\mathrm{KYG}^{\mathrm{T}}$ possessed a distinctive bipolar appearance due to highly refractile intracellular granules of poly- $\beta$-hydroxybutyrate at each cell pole (Fig. 1a, b). However, in contrast to the genus Methylocella, thin-sectioned cells of strain $\mathrm{KYG}^{\mathrm{T}}$ displayed well-developed ICMs packed in parallel to one side of the cell (Fig. 1b). This type of arrangement has been revealed previously in the cells of only one other methanotroph, Methylocapsa acidiphila $\mathrm{B} 2^{\mathrm{T}}$, and has been termed a type III arrangement (Dedysh et al., 2002).

Strain $\mathrm{KYG}^{\mathrm{T}}$ grew on methane and methanol as sole carbon and energy sources. Weak growth was also observed on formate. Methanol supported growth only at concentrations below $0.1 \%(\mathrm{v} / \mathrm{v})$; the most active growth occurred at $0.05 \%(\mathrm{v} / \mathrm{v})$. The preference for a low methanol concentration is characteristic of Methylocapsa acidiphila $\mathrm{B} 2^{\mathrm{T}}$. In addition to these one-carbon compounds, strain $\mathrm{KYG}^{\mathrm{T}}$ was also able to grow on acetate (Fig. 2). Cultures could be maintained continuously on acetate as the sole carbon and energy source without loss of viability. Acetate is also utilized by the facultative methanotrophs of the genus Methylocella, which possess an sMMO but no pMMO (Dedysh et al., 2005). However, in contrast to members of the genus Methylocella, which display a clear preference for acetate, strain $\mathrm{KYG}^{\mathrm{T}}$ grew better on methane (maximum $\mathrm{OD}_{600} 1.2, \mu=0.018 \mathrm{~h}^{-1}$ ) than on acetate (maximum $\left.\mathrm{OD}_{600} 0.3, \mu=0.006 \mathrm{~h}^{-1}\right)$. No growth was observed on the other multicarbon compounds tested.

The purity of acetate-grown cultures of strain $\mathrm{KYG}^{\mathrm{T}}$ was tested by means of phase-contrast and electron microscopy and by plating onto solid DNMS amended with $0.05 \%$ $(\mathrm{w} / \mathrm{v})$ glucose, fructose or yeast extract and incubation 

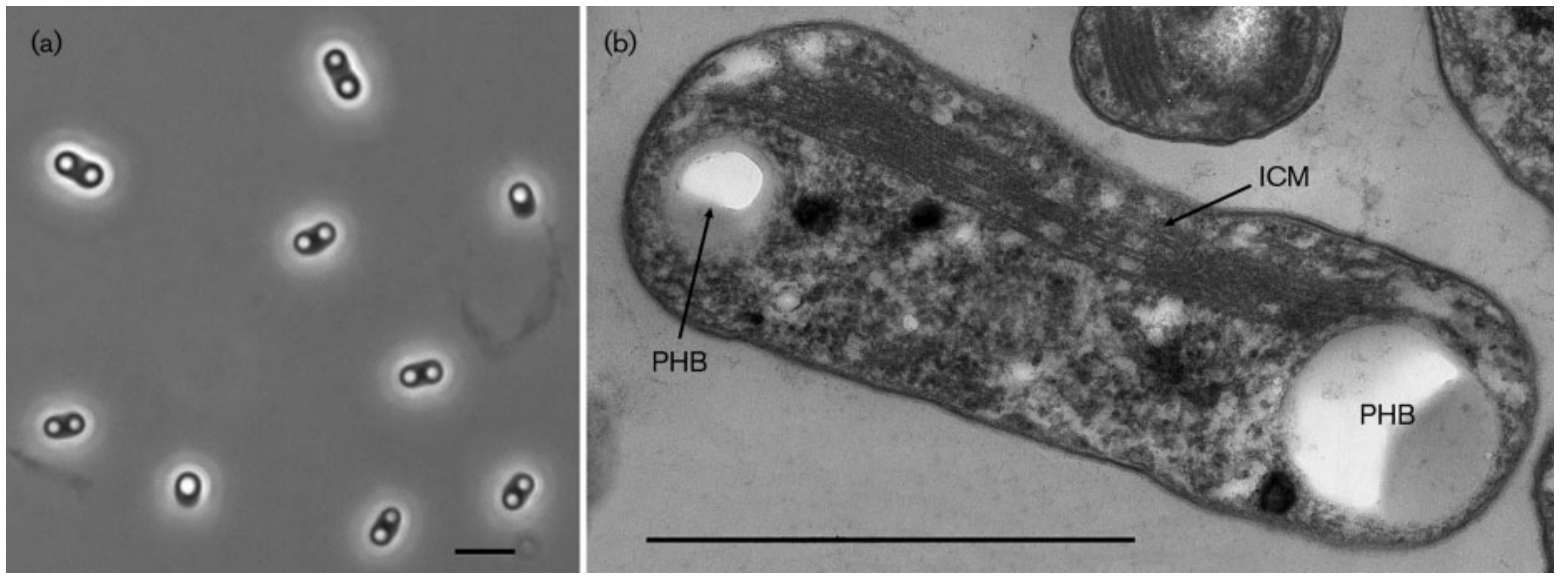

Fig. 1. (a) Phase-contrast micrograph of cells of strain $\mathrm{KYG}^{\top}$, grown in liquid DNMS with methane for 10 days. (b) Electron micrograph of an ultrathin section of a methane-grown cell of strain $\mathrm{KYG}^{\top}$. ICM, Intracytoplasmic membrane; PHB, poly- $\beta$ hydroxybutyrate. Bars, $2 \mu \mathrm{m}$ (a) and $1 \mu \mathrm{m}$ (b).

under a methane-free atmosphere. No growth occurred on these substrates, demonstrating that cultures were not contaminated with organotrophs. Morphology of acetategrown cells was essentially the same as for methane-grown cells, except that acetate-grown cells were more refractile and the cyst-like shape was attained much earlier, after 1.5-2 weeks of growth. ICMs were maintained in acetate-grown cells, although they were present in a reduced form (not shown). Finally, DNA was extracted from acetate-grown and methane-grown cultures and the 16S rRNA gene sequence was amplified by PCR and cloned into Escherichia coli TOP10 using a TA cloning kit (Invitrogen). At least 500 bp from the $5^{\prime}$ end was sequenced from $>21$ clones of each culture. All cloned sequences were the same as that of strain $\mathrm{KYG}^{\mathrm{T}}$, indicating that the growth observed in the acetate culture did not represent a contaminating bacterium.

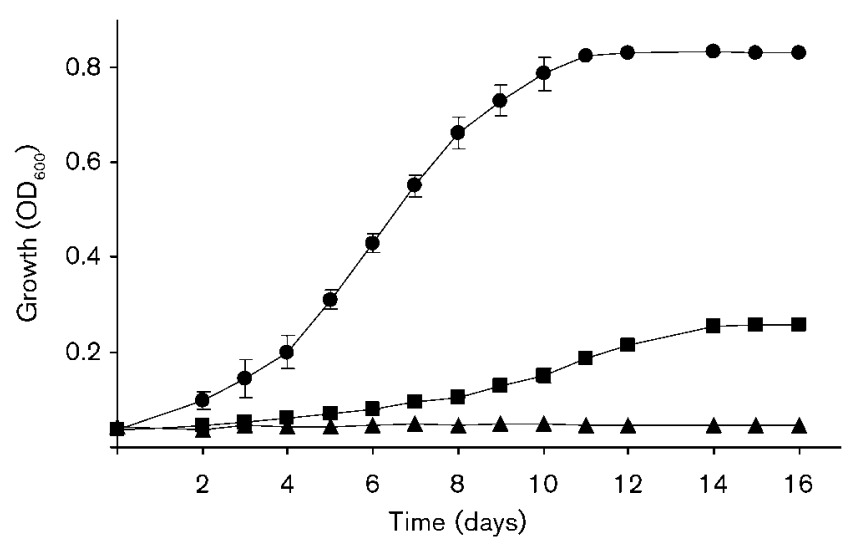

Fig. 2. Growth of strain $\mathrm{KYG}^{\top}$ with methane $(\boldsymbol{\bullet})$ or acetate $(\boldsymbol{\square})$ as the sole carbon and energy source, shown as means of triplicate experiments. $\boldsymbol{\Delta}$, Control with no carbon source. Error bars (where visible) represent the SEM.
The ability to grow on acetate has not been shown for

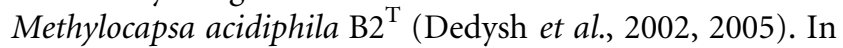
this study, we were able to examine two newly isolated members of this species, strains V1 and N2. Both of these, as well as Methylocapsa acidiphila $\mathrm{B}^{\mathrm{T}}$, were tested for the ability to grow on acetate, ethanol, malate, succinate and pyruvate. For all three strains of Methylocapsa acidiphila, no growth was detected on any of these substrates after 1 month, whereas good growth was observed in the positive controls containing methane. Therefore, we were able to confirm the previous findings that Methylocapsa acidiphila is unable to grow using multicarbon compounds.

Growth of strain $\mathrm{KYG}^{\mathrm{T}}$ occurred over a relatively narrow $\mathrm{pH}$ range, $\mathrm{pH}$ 5.2-7.2 (optimum $\mathrm{pH}$ 6.0-6.2), and no growth occurred below pH 5.0 (Supplementary Fig. S1, available in IJSEM Online). The temperature range for growth was 2$33{ }^{\circ} \mathrm{C}$, with an optimum at $25-30{ }^{\circ} \mathrm{C}$. Strain $\mathrm{KYG}^{\mathrm{T}}$ was extremely sensitive to $\mathrm{NaCl}: 0.1 \%(\mathrm{w} / \mathrm{v}) \mathrm{NaCl}$ inhibited growth by $90 \%$ and $0.2-0.3 \%(\mathrm{w} / \mathrm{v}) \mathrm{NaCl}$ inhibited growth completely. Sole nitrogen sources $(0.05 \%, \mathrm{w} / \mathrm{v})$ included ammonium salts, nitrates, urea, L-proline, L-alanine, Lasparagine, peptone and yeast extract. Strain $\mathrm{KYG}^{\mathrm{T}}$ was also able to fix dinitrogen and a partial nifH sequence was obtained by PCR. However, in contrast to Methylocapsa acidiphila $\mathrm{B}^{\mathrm{T}}$, strain $\mathrm{KYG}^{\mathrm{T}}$ was not capable of active growth in nitrogen-free medium under fully aerobic conditions (Dedysh et al., 2004a).

The cellular fatty acid profile of strain $\mathrm{KYG}^{\mathrm{T}}$ was very similar to those of Methylocapsa acidiphila $\mathrm{B}^{\mathrm{T}}$ and members of the genus Methylocella (Table 1). The major cellular fatty acid in all of these methanotrophs was 11-cisoctadecanoic acid $\left(\mathrm{C}_{18: 1} \omega 7 c\right)$, comprising $59-82 \%$ of the total fatty acids. Despite small differences in some minor components (e.g. $\mathrm{C}_{17: 1} \omega 7 c, \mathrm{C}_{18: 0}$ and $\mathrm{C}_{19: 0}$ cyclo $\omega 8 c$ ), strain $\mathrm{KYG}^{\mathrm{T}}$ and Methylocapsa acidiphila $\mathrm{B}_{2}^{\mathrm{T}}$ were nearly indistinguishable from each other on the basis of their cellular fatty acid profiles. 
Table 1. Cellular fatty acid compositions of strain $\mathrm{KYG}^{\top}$ and related taxa

Values are percentages of total fatty acids and were taken from this study, Dedysh et al. (2000, 2002, 2004b) and Dunfield et al. (2003). -, Not detected/not reported.

\begin{tabular}{|lccc|}
\hline Fatty acid & Strain KYG $^{\mathbf{T}}$ & $\begin{array}{c}\text { Methylocapsa } \\
\text { acidiphila } \text { B2 }^{\mathbf{T}}\end{array}$ & Methylocella \\
\hline $\mathrm{C}_{13: 1}$ & 0.8 & - & - \\
$\mathrm{C}_{14: 0}$ & - & - & $0-4.1$ \\
iso- $\mathrm{C}_{15: 0}$ & 0.3 & 0.1 & $0.2-1.2$ \\
$\mathrm{C}_{15: 0}$ & - & - & $0-0.1$ \\
$\mathrm{C}_{16: 1} \omega 7 c$ & 6.3 & 4.7 & $6.8-11.3$ \\
$\mathrm{C}_{16: 1} \omega 7 t$ & - & - & $0-5.8$ \\
$\mathrm{C}_{16: 1} \omega 5 c$ & - & 0.1 & $0-0.1$ \\
$\mathrm{C}_{16: 0}$ & 5.9 & 7.3 & $3.0-7.7$ \\
iso- $_{17: 1} \omega 9 c$ & 0.2 & - & $0-0.3$ \\
iso- $\mathrm{C}_{17: 0}$ & 0.9 & 0.6 & $0-2.5$ \\
$\mathrm{C}_{17: 1} \omega 8 c$ & - & - & $0-0.3$ \\
$\mathrm{C}_{17: 1} \omega 7 c$ & - & 1.0 & - \\
$\mathrm{C}_{17: 0}$ cyclo & - & - & $0-6.5$ \\
$\mathrm{C}_{17: 0}$ & - & 0.1 & $0-0.1$ \\
iso- $\mathrm{C}_{18: 0}$ & - & - & $0-0.5$ \\
$\mathrm{C}_{18: 1} \omega 9 c$ & 0.4 & - & - \\
$\mathrm{C}_{18: 1} \omega 7 c$ & 81.5 & 78.3 & $59.2-82.2$ \\
$\mathrm{C}_{18: 0}$ & 0.8 & 7.6 & $0.4-1.2$ \\
$\mathrm{C}_{19: 0}$ cyclo & 2.5 & - & $0-13.6$ \\
$\omega 8 c$ & & - & $0-0.6$ \\
$\mathrm{C}_{19: 0}$ & - & & \\
\hline
\end{tabular}

Comparative analysis of $16 \mathrm{~S}$ rRNA gene sequences showed that strain $\mathrm{KYG}^{\mathrm{T}}$ belonged to the family Beijerinckiaceae of the class Alphaproteobacteria and was most closely related to the obligate methanotroph Methylocapsa acidiphila $\mathrm{B} 2^{\mathrm{T}}$ (98.1\% 16S rRNA gene sequence similarity). Other closely related organisms were strains of species of the genera Beijerinckia (97.5-97.7\%) and Methylocella (97.5-97.8\%) and Methylovirgula ligni (96.8\%). In a neighbour-joining analysis, strain $\mathrm{KYG}^{\mathrm{T}}$ clustered most closely with Methylocapsa acidiphila $\mathrm{B} 2^{\mathrm{T}}$, although the node was not supported by a high bootstrap value (40\%; Fig. 3). Tree topologies were constructed using the maximum-likelihood, maximum-parsimony and maximum-likelihood quartet puzzling methods with different distance corrections but failed to produce a consistent affiliation of strain $\mathrm{KYG}^{\mathrm{T}}$ to any particular genus in the family Beijerinckiaceae, and bootstrap and support values were typically $<50 \%$. In some constructions, strain $\mathrm{KYG}^{\mathrm{T}}$ affiliated more closely to the genera Methylocella, Methylovirgula or Beijerinckia than to Methylocapsa acidiphila $\mathrm{B} 2^{\mathrm{T}}$. On the basis of the physiological data, we assign strain $\mathrm{KYG}^{\mathrm{T}}$ to the genus Methylocapsa; however, it may be evolutionarily intermediate to the genus Methylocapsa and other genera.

pmoA was detected in strain $\mathrm{KYG}^{\mathrm{T}}$ by PCR using primers A189f and A682r as described by Heyer et al. (2002), which indicated the presence of pMMO. Amplification from strain $\mathrm{KYG}^{\mathrm{T}}$ was weak compared with DNA extracts from other methanotrophs, which suggested that this primer set may not be well targeted to $p m o A$ in strain $\mathrm{KYG}^{\mathrm{T}}$. To determine the presence of $m m o X$, which encodes a subunit of sMMO, four PCR primer pairs, $166 \mathrm{f}$ and $1401 \mathrm{r}$ (mmoXA and mmoXD), 166f and 1353r [mmoXA and mmoXmcl (5'-VCGYTCGCCCCARTCRTC-3')], 166f and 1272r [mmoXA and mmoXmc2 (5'-VGTCGGGCAGAASGGCAC-3')] and 786f and 1353r [mmoXmc3 (5'-CCGGCSGCSCAGAAATAT- $3^{\prime}$ ) and mmoXmcl], were used with a PCR protocol consisting of denaturation at $94{ }^{\circ} \mathrm{C}$ for $1 \mathrm{~min}$, primer annealing at $55{ }^{\circ} \mathrm{C}$ for $1 \mathrm{~min}$ and extension at $72{ }^{\circ} \mathrm{C}$ for $1 \mathrm{~min}$ for 35 cycles, with a final extension step of $7 \mathrm{~min}$. Primers 166f and 1401r target a wide range of $m m o X$ sequences in methanotrophs (Auman et al., 2000; Heyer et al., 2002). Primers 1353r, 1272r and $786 \mathrm{f}$ were designed to target $m m o X$ sequences specific to methanotrophs in the family Beijerinckiaceae on the basis of all known published sequences plus several unpublished sequences from Methylocella-like isolates in our collection. DNA from Methylocella silvestris $\mathrm{BL}^{\mathrm{T}}$ was used as a positive control. No $m m o X$ sequences were detected in strain $\mathrm{KYG}^{\mathrm{T}}$. The colorimetric naphthalene oxidation test (Graham et al., 1992) for sMMO activity was performed with cells of strain $\mathrm{KYG}^{\mathrm{T}}$ grown on copper-free medium and also gave a negative result. The results strongly suggested that sMMO was not present in strain $\mathrm{KYG}^{\mathrm{T}}$.

A phylogenetic tree based on partial $p m o A$ and amo $A$ sequences (495 nt positions) was constructed using TreePuzzle, a maximum-likelihood quartet-puzzling method, with the Schöniger-von Haeseler distance correction method (Schmidt et al., 2002). Support values for nodes were calculated on the basis of 5000 puzzling steps. The tree showed that strain $\mathrm{KYG}^{\mathrm{T}}$ belonged to the lineage of $\mathrm{pMMO}$ possessing methanotrophs defined by Methylocapsa acidiphila $\mathrm{B} 2^{\mathrm{T}}$ (84.7\% pmoA sequence similarity, $91.4 \%$ deduced amino acid sequence identity) (Fig. 4). The pmoA sequences from the two Methylocapsa species were closely related to pmoA sequences detected by cultivation-independent methods from several soils and peats, including the upland soil cluster alpha that is widely distributed in acidic upland soils and is assumed to represent methanotrophs adapted to consuming the trace level of methane in the atmosphere (Holmes et al., 1999; Knief et al., 2003). So far, these methanotrophs have eluded all attempts at cultivation.

The partial nifH sequence from strain $\mathrm{KYG}^{\mathrm{T}}$ displayed the highest similarity with those of Methylocapsa acidiphila $\mathrm{B} 2^{\mathrm{T}}$ and Beijerinckia indica subsp. indica ATCC $9039^{\mathrm{T}}(92.0 \%$ nifH sequence similarity, $99.0 \%$ deduced amino acid sequence identity). However, unexpectedly, the partial mxaF sequence of strain $\mathrm{KYG}^{\mathrm{T}}$ was most closely related to $m x a F$ fragments from members of the genera Methylobacterium (79.8-83.2\% mxaF sequence similarity, 83.4$88.3 \%$ deduced amino acid sequence identity) and Methylocella (79.0-80.1 and 84.2-85.3\%, respectively) and was less related to Methylocapsa acidiphila $\mathrm{B} 2^{\mathrm{T}}(76.1$ and $78.4 \%$, respectively). 


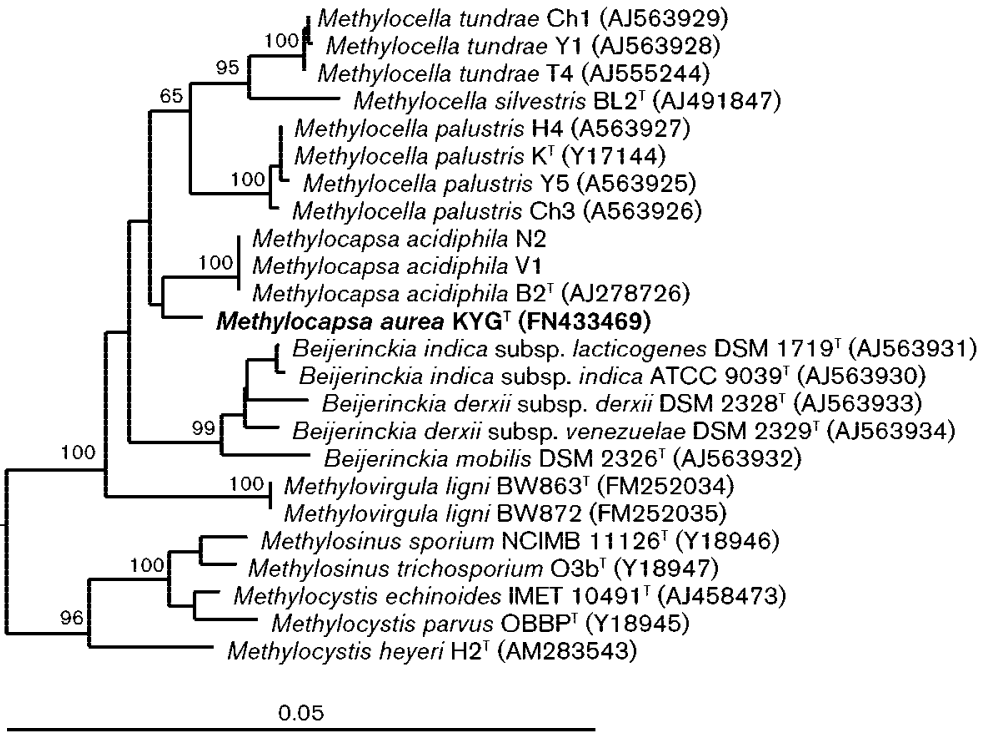

Fig. 3. Phylogenetic tree based on $16 \mathrm{~S}$ rRNA gene sequences, constructed using the neighbour-joining method with Jukes-Cantor correction, showing the position of strain $\mathrm{KYG}^{\top}$ in relation to representatives of the families Beijerinckiaceae and Methylocystaceae. Bootstrap values $(>50 \%)$ based on 1000 resamplings are shown at branch nodes. Sequences from the type-I methanotrophs Methylomicrobium album ACM $3314^{\top}$ (GenBank accession no. X72777), Methylobacter luteus NCIMB 11914 ${ }^{\top}$ (AF304195), Methylomonas methanica $\mathrm{S}^{\top}{ }^{\top}$ (AF304196) and Methylococcus capsulatus Texas $^{\top}$ (AJ563935) were used as an outgroup (not shown). Bar, 0.05 substitutions per nucleotide position.
In summary, strain $\mathrm{KYG}^{\mathrm{T}}$ was shown to be most similar to Methylocapsa acidiphila $\mathrm{B} 2^{\mathrm{T}}$ on the basis of pMMO-based methanotrophy, possession of a well-developed ICM system, utilization of methanol at low concentrations and preference for growth on methane. These phenotypic similarities were supported by phylogenetic analyses of the $16 \mathrm{~S}$ rRNA gene, $p m o A$ and nifH sequences. However, there were differences in substrate utilization patterns, cell morphology and pigmentation, $\mathrm{pH}$ range for growth and efficiency of dinitrogen fixation. The key difference between strain $\mathrm{KYG}^{\mathrm{T}}$ and Methylocapsa acidiphila $\mathrm{B}^{\mathrm{T}}$ was the facultative methanotrophy in strain $\mathrm{KYG}^{\mathrm{T}}$ versus the obligate methanotrophy in Methylocapsa acidiphila
$\mathrm{B} 2^{\mathrm{T}}$. Using two novel isolates of Methylocapsa acidiphila, strains V1 and N2, we were able to confirm that obligate methanotrophy is a feature consistent for the species Methylocapsa acidiphila. Therefore, we propose that strain $\mathrm{KYG}^{\mathrm{T}}$ be classified in a novel species of the genus Methylocapsa, with the name Methylocapsa aurea sp. nov.

\section{Emended description of the genus Methylocapsa Dedysh et al. 2002}

Gram-negative, curved coccoids or thick curved rods that occur singly or in conglomerates, but do not form rosettes. Reproduce by normal cell division. Non-motile.

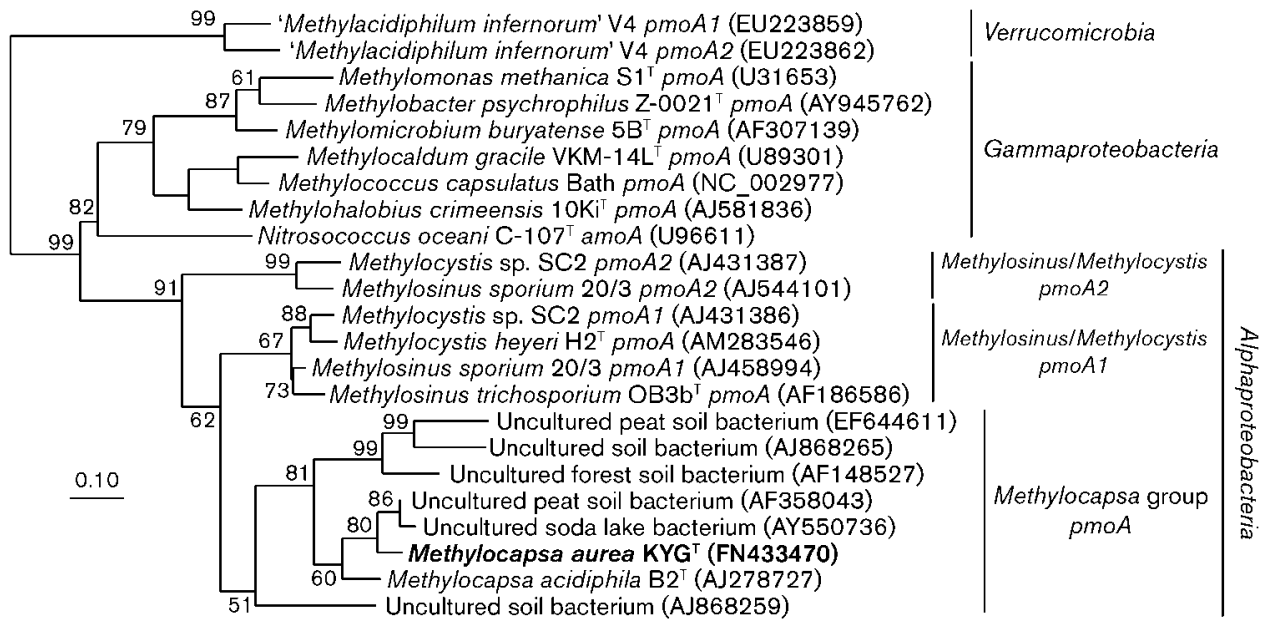

Fig. 4. Phylogenetic tree based on partial (495 nt) $p m o A$ and $a m o A$ sequences, constructed using a quartet maximumlikelihood method and Schöniger-von Haeseler distance correction, showing the relationships between strain $\mathrm{KYG}^{\top}$, other methane- or ammonia-oxidizing bacteria and sequences obtained from cultivation-independent studies of various environments. Support values $(>50 \%)$ based on 5000 puzzling steps are shown at branch nodes. Where the support value is $<50 \%$ a multifurcation is drawn. Bar, 0.1 changes per nucleotide position. 
Encapsulated. Produce intracellular poly- $\beta$-hydroxybutyrate granules. Cells contain a well-developed ICM system of type III arrangement, which appears as stacks of membrane vesicles packed in parallel on only one side of the cell membrane. Strictly aerobic. Possess pMMO and do not express sMMO. Moderately acidophilic and mesophilic. Prefer dilute media with low salt content. Some members of the genus are obligate utilizers of one-carbon compounds, while others are also capable of growth on acetate, but sugars are not utilized. One-carbon compounds are utilized via the serine pathway. Capable of atmospheric nitrogen fixation. The major cellular fatty acid is $\mathrm{C}_{18: 1} \omega 7 c$. The $\mathrm{G}+\mathrm{C}$ content of the DNA is $61.4-63.1 \mathrm{~mol} \%$. Member of the family Beijerinckiaceae in the class Alphaproteobacteria. Known habitats are acidic and nearly neutral wetlands, soils and sediments. The type species is Methylocapsa acidiphila.

\section{Description of Methylocapsa aurea sp. nov.}

Methylocapsa aurea (au're.a. L. fem. adj. aurea golden, referring to the colony colour).

Displays the properties described for the genus, including those in the emended description above, with the following additional traits. Cells are 0.7-1.2 $\mu \mathrm{m}$ wide and 1.8-3.1 $\mu \mathrm{m}$ long. Colonies are yellow. Carbon sources include methane, methanol, formate and acetate. Nitrogen sources are ammonium salts, nitrates, urea, L-proline, L-alanine, Lasparagine, peptone and yeast extract. Dinitrogen is fixed via oxygen-sensitive dinitrogenase. Optimal growth occurs at $25-30{ }^{\circ} \mathrm{C}$ and $\mathrm{pH} 6.0-6.2$. Growth is inhibited with $0.3 \%(\mathrm{w} / \mathrm{v}) \mathrm{NaCl}$. The DNA G $+\mathrm{C}$ content of the type strain is $61.4 \mathrm{~mol} \%$.

The type strain is $\mathrm{KYG}^{\mathrm{T}}\left(=\mathrm{DSM} 22158^{\mathrm{T}}=\mathrm{VKM} \mathrm{B}-2544^{\mathrm{T}}\right)$, isolated from a forest soil near Marburg, Germany.

\section{Acknowledgements}

This research was supported by the programmes 'Molecular and Cell Biology' and 'Biodiversity' of the Russian Academy of Sciences and the Russian Fund of Basic Research (project no. 09-04-91332), by the Max Planck Society and by a Discovery Grant from the Natural Sciences and Engineering Research Council of Canada. The authors thank N. E. Suzina for electron microscopy and E. N. Detkova for DNA G + C content analysis.

\section{References}

Auman, A. J., Stolyar, S., Costello, A. M. \& Lidstrom, M. E. (2000). Molecular characterization of methanotrophic isolates from freshwater lake sediment. Appl Environ Microbiol 66, 5259-5266.

Dedysh, S. N., Panikov, N. S. \& Tiedje, J. M. (1998). Acidophilic methanotrophic communities from Sphagnum peat bogs. Appl Environ Microbiol 64, 922-929.

Dedysh, S. N., Liesack, W., Khmelenina, V. N., Suzina, N. E., Trotsenko, Y. A., Semrau, J. D., Bares, A. M., Panikov, N. S. \& Tiedje, J. M. (2000). Methylocella palustris gen. nov., sp. nov., a new methaneoxidizing acidophilic bacterium from peat bogs, representing a novel subtype of serine-pathway methanotrophs. Int J Syst Evol Microbiol 50, 955-969.

Dedysh, S. N., Derakshani, M. \& Liesack, W. (2001). Detection and enumeration of methanotrophs in acidic Sphagnum peat by $16 \mathrm{~S}$ rRNA fluorescence in situ hybridization, including the use of newly developed oligonucleotide probes for Methylocella palustris. Appl Environ Microbiol 67, 4850-4857.

Dedysh, S. N., Khmelenina, V. N., Suzina, N. E., Trotsenko, Y. A., Semrau, J. D., Liesack, W. \& Tiedje, J. M. (2002). Methylocapsa acidiphila gen. nov., sp. nov., a novel methane-oxidizing and dinitrogen-fixing acidophilic bacterium from Sphagnum bog. Int $J$ Syst Evol Microbiol 52, 251-261.

Dedysh, S. N., Dunfield, P. F., Derakshani, M., Stubner, S., Heyer, J. \& Liesack, W. (2003). Differential detection of type II methanotrophic bacteria in acidic peatlands using newly developed $16 \mathrm{~S}$ rRNA-targeted fluorescent oligonucleotide probes. FEMS Microbiol Ecol 43, 299-308.

Dedysh, S. N., Ricke, P. \& Liesack, W. (2004a). NifH and NifD phylogenies: an evolutionary basis for understanding nitrogen fixation capabilities of methanotrophic bacteria. Microbiology 150, 1301-1313.

Dedysh, S. N., Berestovskaya, Y. Y., Vasylieva, L. V., Belova, S. E., Khmelenina, V. N., Suzina, N. E., Trotsenko, Y. A., Liesack, W. \& Zavarzin, G. A. (2004b). Methylocella tundrae sp. nov., a novel methanotrophic bacterium from acidic tundra peatlands. Int J Syst Evol Microbiol 54, 151-156.

Dedysh, S. N., Knief, C. \& Dunfield, P. (2005). Methylocella species are facultatively methanotrophic. J Bacteriol 187, 4665-4670.

Dunfield, P. F., Khmelenina, V. N., Suzina, N. E., Trotsenko, Y. A. \& Dedysh, S. N. (2003). Methylocella silvestris sp. nov., a novel methanotrophic bacterium isolated from an acidic forest cambisol. Int J Syst Evol Microbiol 53, 1231-1239.

Graham, D. W., Korich, D. G., LeBlanc, R. P., Sinclair, N. P. \& Arnold, R. G. (1992). Applications of a colorimetric plate assay for soluble methane monooxygenase activity. Appl Environ Microbiol 58, 22312236.

Heyer, J., Galchenko, V. F. \& Dunfield, P. F. (2002). Molecular phylogeny of type II methane-oxidizing bacteria isolated from various environments. Microbiology 148, 2831-2846.

Holmes, A. J., Roslev, P., McDonald, I. R., Iversen, N., Henriksen, K. \& Murrell, J. C. (1999). Characterization of methanotrophic bacterial populations in soils showing atmospheric methane uptake. Appl Environ Microbiol 65, 3312-3318.

Kämpfer, P. \& Kroppenstedt, R. M. (1996). Numerical analysis of fatty acid patterns of coryneform bacteria and related taxa. Can $J$ Microbiol 42, 989-1005.

Knief, C., Lipski, A. \& Dunfield, P. F. (2003). Diversity and activity of methanotrophic bacteria in different upland soils. Appl Environ Microbiol 69, 6703-6714.

Ludwig, W., Strunk, O., Westram, R., Richter, L., Meier, H., Yadhukumar, Buchner, A., Lai, T., Steppi, S. \& other authors (2004). ARB: a software environment for sequence data. Nucleic Acids Res 32, 1363-1371.

Op den Camp, H. J. M., Islam, T., Stott, M. B., Harhangi, H. R., Hynes, A., Schouten, S., Jetten, M. S. M., Birkeland, N.-K., Pol, A. \& Dunfield, P. F. (2009). Environmental, genomic and taxonomic perspectives on methanotrophic Verrucomicrobia. Environ Microbiol Rep 1, 293-306.

Owen, R. J., Lapage, S. P. \& Hill, L. R. (1969). Determination of base composition from melting profiles in dilute buffers. Biopolymers 7 , 503-516.

Schmidt, H. A., Strimmer, K., Vingron, M. \& von Haeseler, A. (2002). TREE-PUZZLE: maximum likelihood phylogenetic analysis using quartets and parallel computing. Bioinformatics 18, 502-504. 